\title{
ANALISIS PREFERENSI DAN RUTE DESTINASI PARIWISATA PANTAI DI DAERAH ISTIMEWA YOGYAKARTA
}

\author{
Henny Widyastuti, Agam Marsoyo, Bakti Setiawan \\ Dinas Pekerjaan Umum, Perumahan, dan Kawasan Permukiman Kabupaten Sleman \\ Jalan Magelang km 10 Sleman, Daerah Istimewa Yogyakarta 55511 - Telp (0274) 868501 \\ e-mail: henny.widya586@gmail.com
}

\begin{abstract}
ABSTRAK
Destinasi pariwisata andalan di Daerah Istimewa Yogyakarta adalah destinasi pariwisata pantai. Aksesibilitas yang terdapat dalam destinasi pariwisata pantai tidak menyurutkan minat wisatawan. Tujuan studi ini adalah untuk menggambarkan hubungan antara aksesibilitas dengan preferensi dan rute destinasi pariwisata pantai, serta mengidentifikasi faktor-faktor yang mempengaruhi preferensi dan rute destinasi pariwisata pantai di Daerah Istimewa Yogyakarta. Metode yang digunakan adalah metode deduktif dengan analisa kuantitatif. Metode analisis data yang digunakan yaitu menggunakan analisis statistik deskriptif. Hasil analisis menunjukkan bahwa terdapat hubungan antara aksesibilitas dengan preferensi dan rute destinasi pariwisata pantai. Terdapat destinasi pariwisata pantai yang sering dilewati dan menjadi rujukan yaitu Pantai Baron dan Pantai Parangtritis. Faktor yang mempengaruhi preferensi dan rute destinasi pariwisata pantai adalah (i) faktor sosio-demografis wisatawan, yang terdiri dari daerah asal wisatawan, sumber informasi, dan frekuensi berwisata, (ii) faktor amenitas yang meliputi ketersediaan sarana dan prasarana pariwisata serta kemampuan sarana dan prasarana pariwisata dalam memenuhi kebutuhan wisatawan, (iii) faktor perilaku wisatawan, yang terdiri dari tujuan wisata, motivasi wisata, dan harapan wisatawan akan sarana dan prasarana pariwisata yang dibutuhkan, (iv) faktor atraksi wisata yang meliputi kemampuan atraksi wisata dalam menarik minat wisatawan, jenis atraksi wisata yang digemari wisatawan, dan aktivitas wisata yang dilakukan oleh wisatawan.
\end{abstract}

Kata Kunci : Preferensi, Rute, Destinasi Pariwisata Pantai, Daerah Istimewa Yogyakarta.

\section{ABSTRACT}

The mainstay tourism destinations in Yogyakarta Special Region are beach tourism destinations. Accessibility in beach tourism destinations does not deter tourists. The purpose of this study is to illustrate the relationship between accessibility to preferences and routes of beach tourism destinations, and identify factors affecting the preferences and routes of beach tourism destinations in Yogyakarta Special Region. The method used is deductive method with quantitative analysis. The analysis method used is using descriptive statistical analysis. The result of the analysis shows that there is a relation between accessibility with preference and route of beach tourism destination. There are beach tourism destinations that are often bypassed and become the referral of Baron Beach and Parangtritis Beach. Factors influencing the preferences and routes of beach tourism destinations are (i) the socio-demographic factor of tourists, consisting of the area of origin of tourists, the source of information, and the frequency of travel, (ii) the amenity factor which includes the availability of tourism facilities and infrastructure and the ability of facilities and infrastructure tourism in meeting the needs of tourists, (iii) tourist behavior factor, consisting of tourist destinations, tourism motivation, and tourist expectations of tourism facilities and infrastructure needed, (iv) tourist attraction factors that include the ability of tourist attractions in attracting tourists, tourist attractions are popular tourists, and tourist activities undertaken by tourists

Keywords: Preferences, Routes, Beach Tourism Destinations, Yogyakarta Special Region.

\section{PENDAHULUAN}

Sektor pariwisata merupakan salah satu sektor dalam bidang ekonomi yang mempunyai prospek yang cerah. Pada masa globalisasi ini, pembangunan pariwisata menjadi prioritas utama dalam menunjang pembangunan daerah. Pembangunan kepariwisataan diwujudkan dengan memperhatikan keanekaragaman, keunikan, dan kekhasan budaya dan alam, serta kebutuhan manusia untuk berwisata (UU Nomor 10 Tahun 2009 tentang Kepariwisataan pasal 6). Pembangunan kepariwisataan ini meliputi industri pariwisata dan destinasi pariwisata.

Salah satu kekhasan alam yang dapat dijadikan destinasi pariwisata adalah pantai. Daerah pantai merupakan suatu daratan beserta perairannya dimana pada daerah tersebut masih saling dipengaruhi baik oleh aktivitas darat maupun laut (marine) (Peraturan Menteri 
Pekerjaan Umum Nomor 9 Tahun 2010 tentang Pedoman Pengamanan Pantai).

Salah satu destinasi pariwisata pantai yang menjadi andalan bagi Daerah Istimewa Yogyakarta adalah destinasi pariwisata pantai, dimana setiap destinasi pariwisata pantai memiliki karakteristik dan keunikan yang berbeda-beda. Karakteristik dan keunikan tersebut disebabkan oleh faktor geografis lokasi destinasi pariwisata pantai.

Pada saat ini banyak destinasi pariwisata pantai yang berkembang di Daerah Istimewa Yogyakarta namun realitanya wisatawan hanya mengunjungi destinasi pariwisata pantai tertentu sehingga menimbulkan adanya tingkat kunjungan yang berbeda-beda di setiap destinasi pariwisata pantai. Berdasarkan data statistik jumlah pengunjung destinasi pariwisata pantai di Daerah Istimewa Yogyakarta, terdapat perbedaan rata-rat jumlah kunjungan yang cukup signifikan pada destinasi pariwisata pantai selama tiga tahun terakhir (Gambar 1).

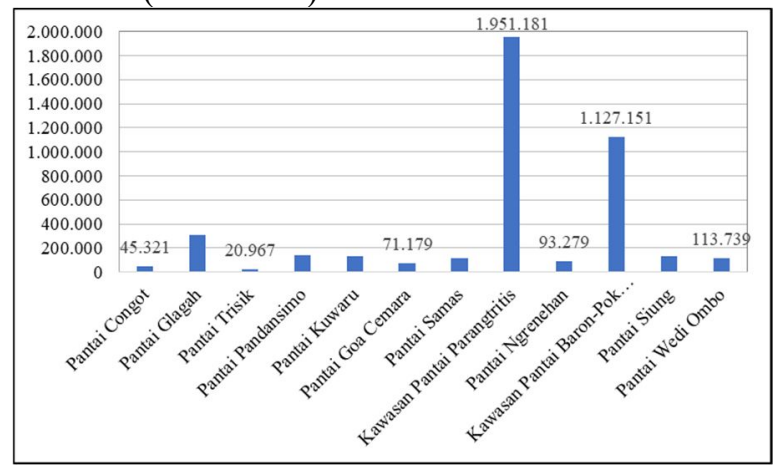

Gambar 1 Grafik Rata-Rata Kunjungan Wisatawan Tahun 2014-2016

Perbedaan jumlah kunjungan tersebut memicu adanya kesenjangan antar destinasi pariwisata karena adanya ketidak seimbangan pergerakan wisatawan. Ketidak seimbangan pergerakan wisatawan tersebut akan berpengaruh terhadap interaksi antar wilayah di sekitar destinasi pariwisata pantai. Setiap pergerakan wisatawan dipengaruhi oleh preferensi dalam melakukan kegiatan wisata dan memiliki rute perjalanan yang berbeda-beda. Aksesibilitas yang terdapat pada destinasi pariwisata pantai juga tidak menyurutkan minat wisatawan untuk berkunjung ke destinasi pariwisata pantai. Terdapat destinasi pariwisata pantai yang mempunyai aksesibilitas yang kurang baik, namun tingkat kunjungan wisatawan tiap tahunnya meningkat. Hal tersebut menandakan bahwa aksesibilitas tidak berpengaruh terhadap pergerakan wisatawan.

Berdasarkan latar belakang tersebut maka perlu dilakukan penelitian mengenai hubungan antara aksesibilitas dengan preferensi dan rute destinasi pariwisata pantai dan faktor yang mempengaruhi preferensi dan rute destinasi pariwisata pantai.

\section{METODE PENELITIAN}

Penelitian ini merupakan penelitian deduktif dengan metode analisa secara kuantitatif. Metode penelitian diartikan sebagai cara ilmiah untuk mendapatkan data dengan tujuan dan kegunaan tertentu (Sugiyono, 2009). Penelitian kuantitatif merupakan penelitian yang banyak dituntut mengggunakan angka, mulai dari pengumpulan data, penafsiran data tersebut, serta penampilan hasilnya (Arikunto, 2010). Data yang digunakan berasal dari data primer yang diperoleh dari hasil survei, observasi lapangan, dan wawancara dengan wisatawan yang berkunjung ke destinasi pariwisata pantai serta data sekunder dari instansi pemerintah terkait data destinasi pariwisata pantai di Daerah Istimewa Yogyakarta.

Penelitian ini berlokasi di dua puluh tiga destinasi pariwisata pantai yang berada di sepanjang pesisir Daerah Istimewa Yogyakarta. Dua puluh tiga destinasi pariwisata pantai dipilih berdasarkan kelengkapan data kunjungan wisatawan selama kurun waktu tujuh tahun terakhir yaitu antara tahun 2010 sampai tahun 2016. Dua puluh tiga destinasi pariwisata pantai yang menjadi lokasi penelitian antara lain Pantai Congot, Pantai Glagah, Pantai Trisik, Pantai Pandansimo, Pantai Kuwaru, Pantai Goa Cemara, Pantai Samas, Pantai Depok, Pantai Parangtritis, Pantai Ngobaran, Pantai Ngrenehan, Pantai Nguyahan, Pantai Baron, Pantai Kukup, Pantai Sepanjang, Pantai Drini, Pantai Krakal, Pantai Ngandong, Pantai Sundak, Pantai Pulang Sawal, Pantai Pok Tunggal, Pantai Siung, dan Pantai Wedi Ombo. Peta lokasi penelitian tersebut dapat dilihat pada gambar berikut (gambar 1).

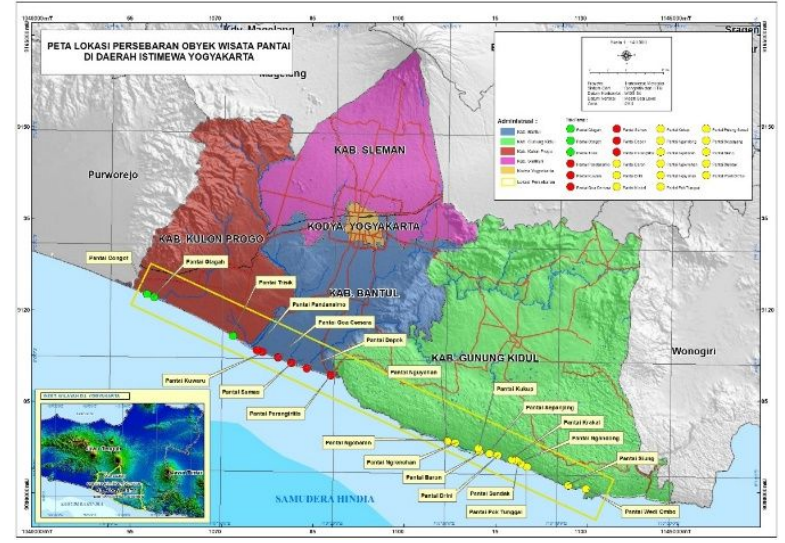

Gambar 2 Peta Lokasi Penelitian

Data yang digunakan untuk menentukan jumlah populasi adalah data Dinas Pariwisata DIY yaitu data jumlah wisatawan yang 
berkunjung di dua puluh tiga destinasi pariwisata pantai yang menjadi lokasi penelitian pada tahun 2016. Jumlah populasi tersebut diketahui sebanyak 5.612.284 orang.

Setelah diketahui jumlah populasi wisatawan yang berkunjung di destinasi pariwisata pantai di Daerah Istimewa Yogyakarta mencapai 5.612.284 orang maka dengan menggunakan rumus berikut.

$$
\mathrm{n}=\frac{\mathrm{N}}{\mathrm{Nd}^{2}+1}=\frac{5612284}{5612284\left(0,05^{2}\right)+1}=399
$$

keterangan:

$\mathrm{N}=$ jumlah populasi

$\mathrm{n}=$ jumlah sampel

$\mathrm{d}=\operatorname{presisi}(\alpha)=95 \%$

Namun, karena prinsipnya semakin banyak sampel semakin baik maka jumlah sampel dibulatkan menjadi 400 responden. Jumlah wisatawan yang berkunjung ke destinasi pariwisata pantai tidak sama, maka pengambilan sampel dengan menggunakan teknik proportional (random) sampling yaitu teknik pengambilan sampel dengan cara simple random sampling, kemudian diproporsikan sesuai dengan jumlah sub-populasinya sehingga di dapat jumlah sampel yang representatif. Jumlah sampel penelitian di masing-masing lokasi penelitian diperoleh dengan cara membagi jumlah wisatawan per lokasi penelitian dengan total responden dikalikan dengan jumlah sampel. Berikut jumlah sampel penelitian pada masingmasing destinasi pariwisata pantai (Tabel 1)

Tabel 1 Jumlah Sampel Penelitian

\begin{tabular}{|c|c|c|}
\hline NO & $\begin{array}{c}\text { DESTINASI PARIWISATA } \\
\text { PANTAI }\end{array}$ & $\begin{array}{c}\text { JUMLAH } \\
\text { SAMPEL } \\
\text { PENELITIAN }\end{array}$ \\
\hline 1 & Pantai Congot & 4 \\
\hline 2 & Pantai Glagah & 22 \\
\hline 3 & Pantai Trisik & 1 \\
\hline 4 & Pantai Pandansimo & 10 \\
\hline 5 & Pantai Goa Cemara & 6 \\
\hline 6 & Pantai Kuwaru & 4 \\
\hline 7 & Pantai Samas & 18 \\
\hline 8 & Pantai Depok & 53 \\
\hline 9 & Pantai Parangtritis & 106 \\
\hline 10 & Pantai Ngobaran & 4 \\
\hline 11 & Pantai Ngrenehan & 4 \\
\hline 12 & Pantai Nguyahan & 4 \\
\hline 13 & Pantai Baron & 15 \\
\hline 14 & Pantai Kukup & 15 \\
\hline 15 & Pantai Sepanjang & 15 \\
\hline 16 & Pantai Drini & 15 \\
\hline 17 & Pantai Krakal & 15 \\
\hline 18 & Pantai Ngandong & 15 \\
\hline 19 & Pantai Sundak & 15 \\
\hline 20 & Pantai Pulang Sawal & 15 \\
\hline 21 & Pantai Pok Tunggal & 15 \\
\hline 22 & Pantai Siung & 15 \\
\hline \multirow[t]{2}{*}{23} & Pantai Wedi Ombo & 14 \\
\hline & TOTAL & 400 \\
\hline
\end{tabular}

Metode analisis data yang digunakan adalah analisis statistik deskriptif. Analisis statistik deskriptif dipergunakan untuk menyederhanakan data ke dalam bentuk penyajian yang lebih mudah dibaca, seperti tabel, grafik, diagram, perhitungan modus, mean, median, standar deviasi, dan perhitungan persentase. Metode yang digunakan untuk mengidentifikasi rute wisatawan adalah dengan cara mengklasifikasikan rute perjalanan wisatawan yang sudah tercantum di dalam kuesioner yang disebar di tiap-tiap lokasi penelitian, dimana di dalam kuesioner responden sudah mengisi urutan destinasi pariwisata pantai yang akan dikunjungi. Setelah data diklasifikasikan, rute perjalanan tersebut kemudian dibuat skema.

Hipotesis sebagai pernyataan yang bersifat terkaan mengenai hubungan antara dua atau lebih fenomena atau variabel (Kerlinger, 1973). Hipotesis yang dikemukakan dalam penelitian ini adalah sebagai berikut.

1. Dalam menggambarkan hubungan antara aksesibilitas dengan preferensi dan rute destinasi pariwisata pantai, hipotesis yang digunakan adalah tidak adanya hubungan antara aksesibilitas dengan preferensi dan rute destinasi pariwisata pantai. Bila dirumuskan dalam persamaan adalah sebagai berikut.

$\mathrm{H}_{0}$ : Tidak ada hubungan antara aksesibilitas dengan preferensi dan rute destinasi pariwisata pantai.

$\mathrm{H}_{1}$ : Ada hubungan antara aksesibilitas dengan preferensi dan rute destinasi pariwisata pantai.

2. Dalam menggambarkan rute destinasi pariwisata pantai, dapat terlihat destinasi pariwisata pantai yang sering dilewati oleh wisatawan, dan lokasi destinasi pariwisata pantai yang menjadi rujukan bagi wisatawan untuk berkunjung.

3. Dalam menganalisis faktor-faktor yang mempengaruhi preferensi dan rute destinasi pariwisata pantai, hipotesis yang digunakan adalah terdapat perbedaan faktor-faktor yang dominan dalam mempengaruhi preferensi dan rute berdasarkan lokasi destinasi pariwisata pantai. Bila dirumuskan dalam persamaan sebagai berikut.

$\mathrm{H}_{0}$ : Tidak ada perbedaan faktor yang dominan mempengaruhi preferensi dan rute berdasarkan lokasi destinasi pariwisata pantai.

$\mathrm{H}_{1}$ : Ada perbedaan faktor yang dominan mempengaruhi preferensi 
dan rute berdasarkan lokasi destinasi pariwisata pantai.

\section{HASIL DAN PEMBAHASAN}

Analisis data dilakukan dengan menggunakan analisis statistik deskriptif untuk menggambarkan hubungan antara aksesibilita dengan preferensi dan rute destinasi pariwisata pantai serta mengidentifikasi faktor-faktor yang mempengaruhi preferensi dan rute destinasi pariwisata pantai.

\section{Hubungan Antara Aksesibilitas Dengan Preferensi dan Rute Destinasi Pariwisata Pantai}

Dari hasil analisis, diperoleh skema rute destinasi pariwisata pantai di Daerah Istimewa Yogyakarta (Gambar 14). Berdasarkan skema tersebut, terlihat bahwa destinasi pariwisata pantai yang sering dilewati oleh wisatawan dan menjadi rujukan adalah Pantai Baron, Pantai Depok, dan Pantai Parangtritis. Selain itu terdapat juga destinasi pariwisata pantai yang jarang dilewati oleh wisatawan yaitu Pantai Samas dan Pantai Trisik. Hasil analisis memperlihatkan bahwa terdapat hubungan antara aksesibilitas dengan preferensi dan rute destinasi pariwisata pantai. Hal tersebut terlihat dari alasan yang mendasari wisatawan dalem memilih rute perjalanan wisata yaitu lokasi destinasi pariwisata pantai yang berdekatan, jarak tempuh tidak terlalu jauh, serta kemudahan aksesibilitas untuk menuju destinasi pariwisata pantai yang satu ke destinasi pariwisata pantai yang lain.

\section{Faktor yang Mempengaruhi Preferensi dan Rute Destinasi Pariwisata Pantai \\ 1. Preferensi dan Rute Berdasarkan Sosio- Demografis Wisatawan}

Kajian ini dimaksudkan untuk mengetahui preferensi dan rute wisatawan berdasarkan faktor sosio-demografis wisatawan yang dilihat berdasarkan daerah asal wisatawan, sumber informasi yang diperoleh wisatawan, dan frekuensi berwisata wisatawan ke destinasi pariwisata pantai tersebut. Berdasarkan daerah asal wisatawan, wisatawan yang berasal dari dalam DIY mendominasi kunjungan wisata ke destinasi pariwisata pantai yang terdapat di Kabupaten Kulon Progo (51,85\% dari total responden di kabupaten tersebut) dan Kabupaten Gunungkidul $(52,27 \%$ dari total responden di kabupaten tersebut).

Wisatawan yang berkunjung ke destinasi pariwisata pantai di Kabupaten Bantul sebagian besar berasal dari luar DIY dengan persentase sebesar $51,78 \%$ dari total responden di kabupaten tersebut. Hal tersebut diperkirakan karena destinasi pariwisata pantai di Kabupaten Bantul memiliki jarak tempuh yang relatif lebih dekat dari pusat DIY dibandingkan dengan destinasi pariwisata pantai di Kabupaten Kulon Progo dan Kabupaten Gunungkidul.

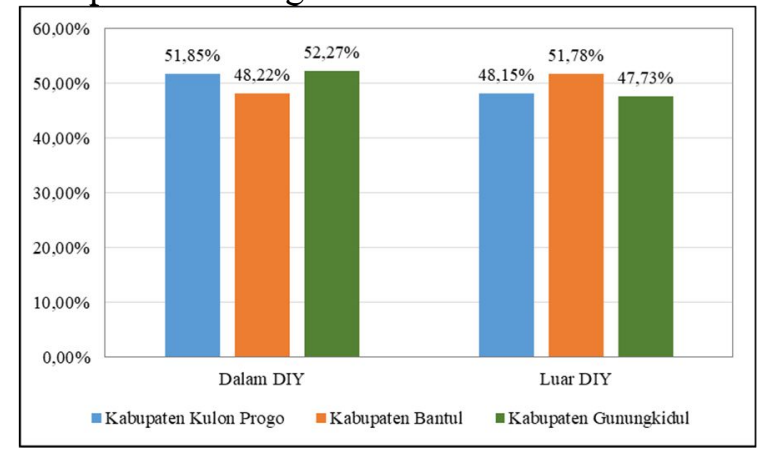

Gambar 3 Grafik Daerah Asal Wisatawan

Selain daerah asal wisatawan, preferensi dan rute juga dapat dilihat dari sumber informasi yang diperoleh wisatawan. Wisatawan yang berkunjung ke destinasi pariwisata pantai di Kabupaten Kulon Progo dan Kabupaten Bantul mayoritas memperoleh informasi terkait pantai dari keluarga maupun teman dengan persentase sebesar 48,15\% dari total responden di Kabupaten Kulon Progo dan 46,70\% dari total responden di Kabupaten Bantul. Hal berbeda terlihat dari wisatawan yang berkunjung ke destinasi pariwisata pantai yang terdapat di Kabupaten Gunungkidul dimana sebagian besar wisatawan memperoleh informasi dari media elektronik dengan persentase sebesar $47,73 \%$ dari total responden di kabupaten tersebut.

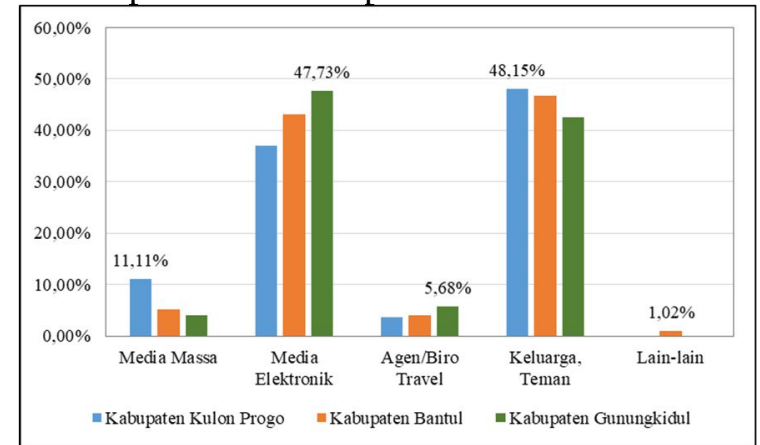

Gambar 4 Grafik Sumber Informasi Wisatawan

Wisatawan yang berkunjung ke destinasi pariwisata pantai di Daerah Istimewa Yogyakarta memiliki keanekaragaman karena terdapat wisatawan yang baru pertama kali melakukan kunjungan ke destinasi pariwisata pantai dan wisatawan yang sudah berulang kali melakukan kunjungan ke destinasi pariwisata pantai. Frekuensi berwisata ini mempengaruhi preferensi dan rute dimana wisatawan akan tertarik untuk mencoba mengunjungi destinasi pariwisata pantai yang belum pernah didatanginya.

Wisatawan yang berkunjung ke destinasi pariwisata pantai di Daerah Istimewa Yogyakarta 
mayoritas baru melakukan kunjungan untuk pertama kalinya ke destinasi pariwisata pantai yang didatangi dengan persentase sebesar 48,15\% dari total responden di Kabupaten Kulon Progo, 32,99\% dari total responden di Kabupaten Bantul, dan 51,14\% dari total responden di Kabupaten Gunungkidul. Hal tersebut dapat diartikan bahwa wisatawan yang berkunjung memiliki rasa ingin tahu yang cukup besar dengan destinasi pariwisata pantai yang terdapat di Daerah Istimewa Yogyakarta.

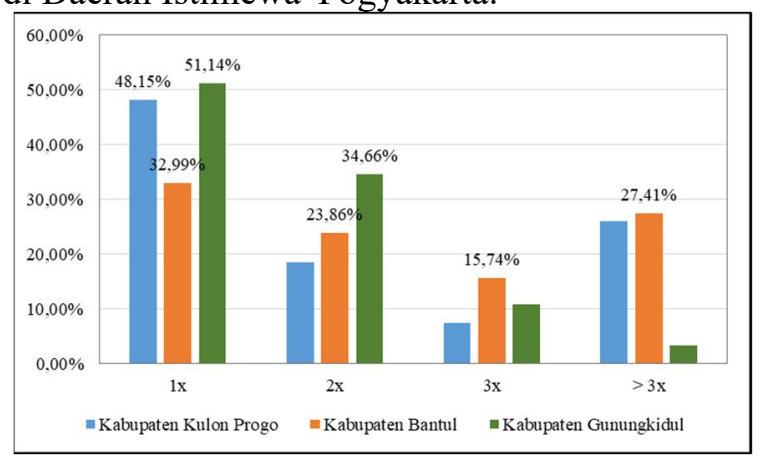

Gambar 5 Grafik Frekuensi Berwisata Wisatawan

\section{Preferensi dan Rute Berdasarkan Amenitas}

Kajian ini dimaksudkan untuk mengetahui preferensi dan rute wisatawan berdasarkan amenitas yang dilihat dari ketersediaan dan kemampuan sarana dan prasarana pariwisata dalam menunjang kebutuhan wisatawan. Dari analisis mengenai ketersediaan sarana dan prasarana pariwisata diperoleh hasil bahwa secara garis besar sarana dan prasarana yang terdapat di destinasi pariwisata pantai di Daerah Istimewa Yogyakarta sudah cukup lengkap dan berupa toilet, restoran, tempat parkir, sarana ibadah, sarana rekreasi dan olahraga, penginapan, toko cinderamata, jaringan listrik, jaringan air bersih, jaringan air minum, jaringan komunikasi, pos keamanan, dan pelayanan kesehatan. Sarana rekreasi dan olahraga yang terdapat di destinasi pariwisata pantai pada umumnya berupa kolam renang anak, spot foto, peyewaan ATV, penyewaan kuda atau bendi, dan wisata jip.

Selain kelengkapan sarana dan prasarana pariwisata yang tersedia di destinasi pariwisata pantai di Daerah Istimewa Yogyakarta, perlu dilihat juga kemampuan sarana dan prasarana pariwisata dalam memenuhi kebutuhan wisatawan. Menurut wisatawan, sarana pariwisata yang terdapat di destinasi pariwisata pantai sudah mampu memenuhi kebutuhan wisatawan yang berkunjung ke destinasi pariwisata pantai, baik yang berlokasi di Kabupaten Kulon Progo $(55,56 \%$ dari total responden di kabupaten tersebut), Kabupaten Bantul (57,36\% dari total responden di kabupaten tersebut), dan Kabupaten Gunungkidul (84,66\% dari total responden di kabupaten tersebut).

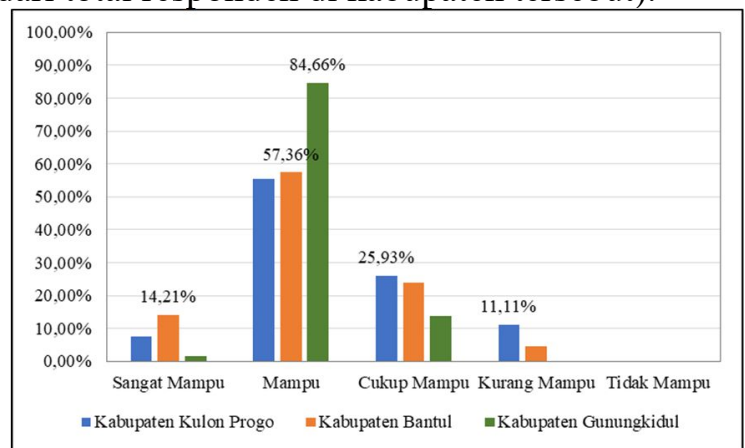

Gambar 6 Grafik Kemampuan Sarana Pariwisata Dalam Memenuhi Kebutuhan Wisatawan

Wisatawan yang berkunjung ke destinasi pariwisata pantai di Kabupaten Kulon Progo $(33,33 \%$ dari total responden di kabupaten tersebut), Kabupaten Bantul (45,18\% dari total responden di kabupaten tersebut), dan Kabupaten Gunungkidul $(81,26 \%$ dari total responden di kabupaten tersebut) mengemukakan bahwa prasarana pariwisata yang tersedia di destinasi pariwisata pantai mampu menunjang kebutuhan wisatawan yang berkunjung.

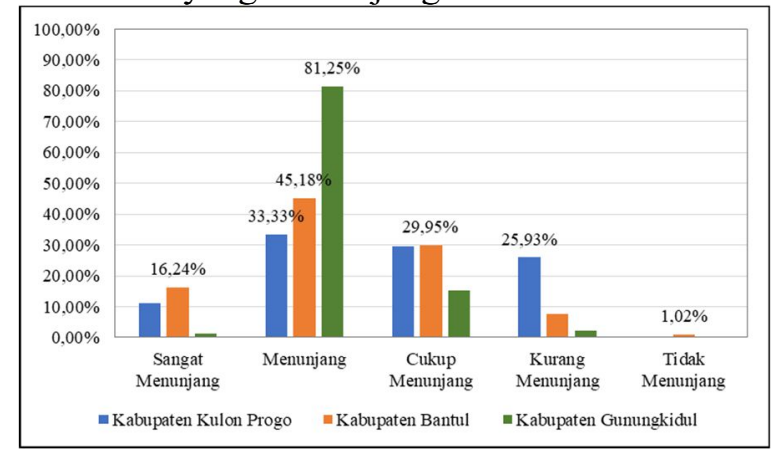

Gambar 7 Grafik Kemampuan Prasarana Pariwisata Dalam Menunjang Kebutuhan Wisatawan

\section{Preferensi dan Rute Berdasarkan Faktor Perilaku Wisatawan}

Kajian ini dimaksudkan untuk mengetahui preferensi dan rute wisatawan berdasarkan faktor perilaku wisatawan yang dilihat dari segi tujuan wisata, motivasi wisatawan, dan harapan wisatawan ketika berkunjung ke destinasi pariwisata pantai di Daerah Istimewa Yogyakarta. Wisatawan yang berkunjung ke destinasi pariwisata pantai di Daerah Istimewa Yogyakarta mayoritas memiliki tujuan wisata untuk liburan dengan persentase sebesar 92,59\% dari total responden di Kabupaten Kulon Progo, $75,13 \%$ dari total responden di Kabupaten Bantul, dan 74,43\% dari total responden di Kabupaten Gunungkidul. Liburan tersebut dapat berupa liburan bersama keluarga, sekolah, maupun bersama teman-teman untuk menghilangkan kejenuhan dari rutinitas seharihari. 


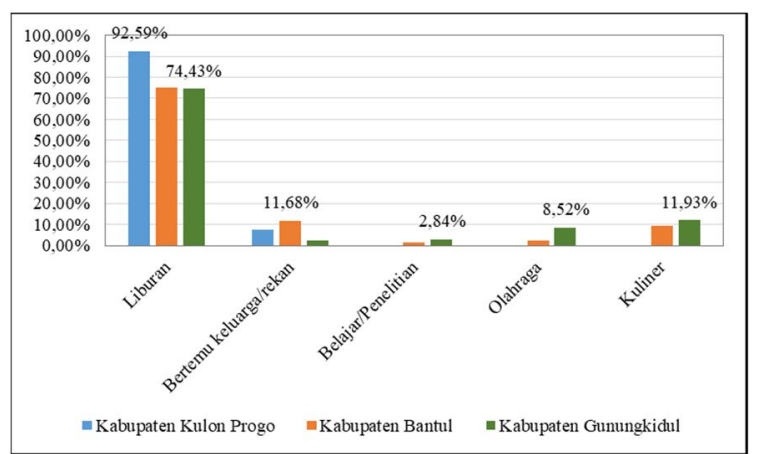

Gambar 8 Grafik Tujuan Wisata Wisatawan

Motivasi wisata didasarkan pada keinginan untuk mendatangi suatu destinasi pariwisata. Motivasi fisik mendominasi motivasi wisatawan yang berkunjung ke destinasi pariwisata pantai di Daerah Istimewa Yogyakarta, baik destinasi pariwisata yang berlokasi di Kabupaten Kulon Progo $(66,67 \%$ dari total responden di kabupaten tersebut), Kabupaten Bantul $(65,99 \%$ dari total responden di kabupaten tersebut), dan Kabupaten Gunungkidul $(68,75 \%$ dari total responden di kabupaten tersebut). Motivasi fisik ini berupa keinginan untuk menikmati keindahan alam sambil berekreasi, berolah raga maupun untuk refreshing.

Selain itu, terdapat juga harapan wisatawan akan sarana dan prasarana pariwisata yang diharapkan bisa tersedia di destinasi pariwisata pantai yang bersifat menarik dengan kualitas yang baik serta mampu mewadahi semua bentuk aktivitas wisatawan. Wisatawan yang berkunjung ke destinasi pariwisata pantai di Daerah Istimewa Yogyakarta mayoritas mengharapkan adanya sarana rekreasi dan olahraga yang menarik dan berkualitas baik dengan persentase sebesar 29,63\% dari total responden di Kabupaten Kulon Progo, 45,69\% dari total responden di Kabupaten Bantul, dan 33,52\% dari total responden di Kabupaten Gunungkidul.

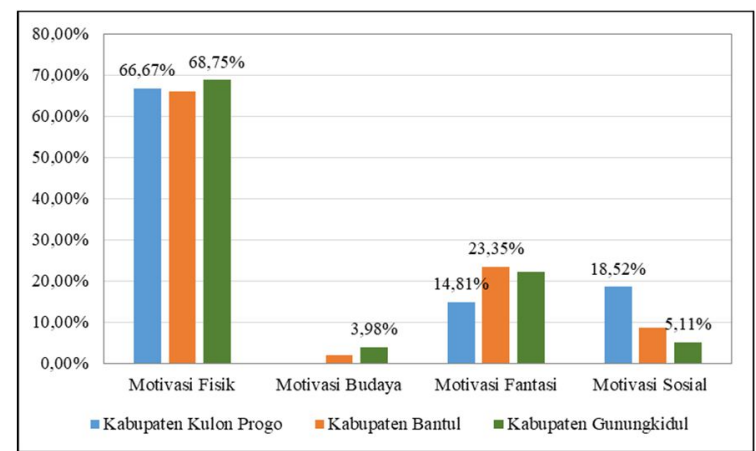

Gambar 9 Grafik Motivasi Wisatawan

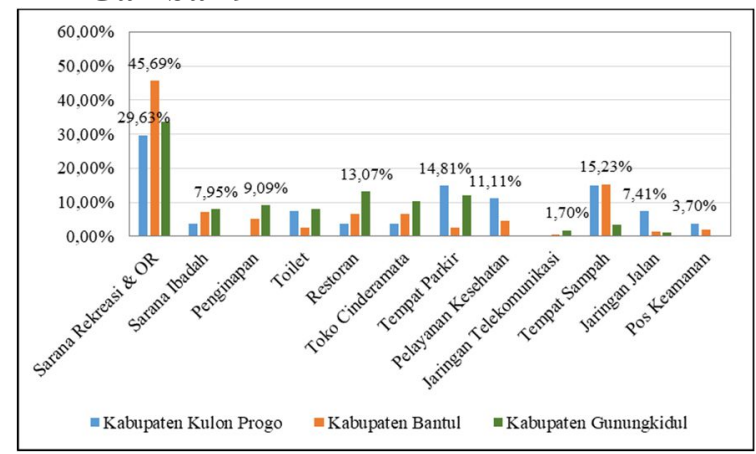

Gambar 10 Grafik Harapan Wisatawan Akan Sarana Prasarana Pariwisata

\section{Preferensi dan Rute Berdasarkan Atraksi Wisata}

Kajian ini dimaksudkan untuk mengetahui preferensi dan rute wisatawan berdasarkan atraksi wisata dalam hal ini dilihat dari segi kemampuan daya tarik wisata di destinasi pariwisata pantai, jenis atraksi wisata yang diminati wisatawan, dan aktivitas wisata yang dilakukan oleh wisatawan selama berada di destinasi pariwisata pantai. Wisatawan yang berkunjung di destinasi pariwisata pantai yang berada di Kabupaten Kulon Progo mengemukakan bahwa daya tarik wisata yang ada mampu menarik minat wisatawan dengan persentase sebesar 48,15\% dari total responden di kabupaten tersebut.

Hal senada disampaikan oleh wisatawan yang berkunjung ke destinasi pariwisata pantai di Kabupaten Bantul bahwa daya tarik wisata yang ada mampu menarik minat wisatawan dengan persentase sebesar $52,28 \%$ dari total responden di kabupaten tersebut. Begitu pula dengan wisatawan yang berkunjung ke destinasi pariwisata pantai di Kabupaten Gunungkidul menyatakan daya tarik wisata mampu menarik minat wisatawan dengan persentase sebesar $78,98 \%$ dari total responden di kabupaten tersebut. 


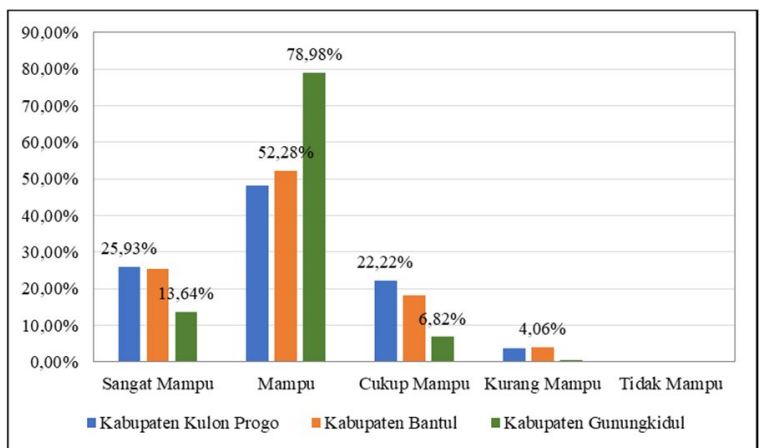

Gambar 11 Grafik Kemampuan Daya Tarik Wisata

Wisatawan yang berkunjung ke destinasi pariwisata pantai di Daerah Istimewa Yogyakarta mayoritas tertarik dengan daya tarik wisata alam dibandingkan dengan daya tarik wisata budaya maupun daya tarik wisata hasil buatan manusia. Wisatawan yang berada di destinasi pariwisata pantai di Kabupaten Kulon Progo menyukai daya tarik wisata alam dengan persentase sebesar $77,78 \%$ dari total responden di kabupaten tersebut.

Begitu pula wisatawan yang berkunjung ke destinasi pariwisata pantai di Kabupaten Bantul juga menyukai daya tarik wisata alam dengan persentase sebesar $74,11 \%$ yang disusul dengan daya tarik wisata budaya dengan persentase sebesar 5,58\% dari total responden di kabupaten tersebut. Wisatawan yang berkunjung di destinasi pariwisata pantai di Kabupaten Gunungkidul juga lebih berminat dengan daya tarik wisata alam dengan persentase sebesar $69,89 \%$ dari total responden di kabupaten tersebut.

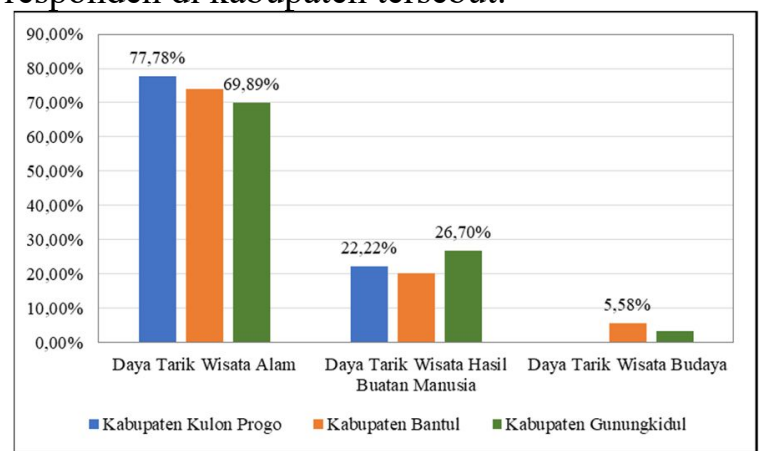

Gambar 12 Grafik Daya Tarik Wisata yang Diminati Oleh Wisatawan

Daya tarik wisata akan semakin menarik dengan adanya ciri khas yang dimiliki oleh destinasi pariwisata pantai yang membedakan dengan destinasi pariwisata pantai yang lain seperti Pantai Glagah yang terkenal dengan pemecah ombaknya, Pantai Depok dengan wisata kulinernya, dan Pantai Baron yang terkenal memiliki sungai bawah tanah. Aktivitas wisatawan yang berkunjung ke destinasi pariwisata pantai di Daerah Istimewa Yogyakarta beraneka macam.
Wisatawan yang berkunjung ke destinasi pariwisata pantai di Kabupaten Kulon Progo mayoritas melakukan aktivitas yaitu berjalanjalan di pinggir pantai $(40,74 \%$ dari total responden di kabupaten tersebut). Hal berbeda dilakukan oleh wisatawan yang berkunjung ke destinasi pariwisata pantai di Kabupaten Bantul dan Kabupaten Gunungkidul, mayoritas aktivitas yang dilakukan oleh wisatawan adalah bermain air $(24,37 \%$ dari total responden di Kabupaten Bantul dan 28,98\% dari total responden di Kabupaten Gunungkidul).

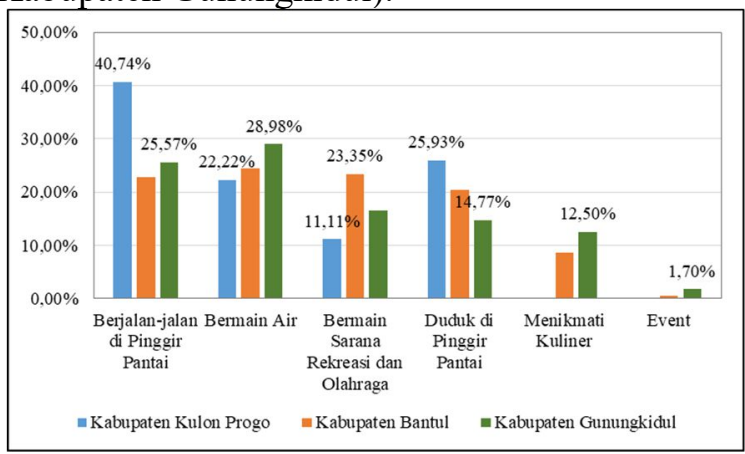

Gambar 13 Grafik Aktivitas Wisata Wisatawan

Atraksi wisata yang terdapat di destinasi pariwisata pantai di Daerah Istimewa Yogyakarta semakin menarik dengan adanya daya tarik wisata tambahan yang ditawarkan kepada wisatawan. Daya tarik wisata tambahan tersebut dapat berupa penyewaan ATV, kolam renang anak, penyewaan bendi, spot foto, surfing, snorkelling, maupun konservasi penyu.

\section{KESIMPULAN}

Dari hasil analisis maka dapat diambil kesimpulan bahwa terdapat hubungan antara aksesibilitas dengan preferensi dan rute destinasi pariwisata pantai. Selain itu, rute perjalanan wisatawan menunjukkan adanya destinasi pariwisata pantai yang menjadi rujukan dan sering dilewati yaitu Pantai Baron dan Pantai Parangtritis dan terdapat pula destinasi pariwisata pantai yang jarang dilewati oleh wisatawan yaitu Pantai Samas dan Pantai Trisik.

Faktor yang mempengaruhi preferensi dan rute destinasi pariwisata pantai adalah (i) faktor sosio-demografis wisatawan yang terdiri dari daerah asal wisatawan, sumber informasi wisatawan, dan frekuensi berwisata wisatawan, (ii) faktor amenitas, meliputi ketersediaan sarana dan prasarana pariwisata serta kemampuan sarana dan prasarana pariwisata dalam memenuhi kebutuhan wisatawan, (iii) faktor perilaku wisatawan yang meliputi tujuan berwisata, motivasi wisata, dan harapan wisatawan akan sarana dan prasaran yang dibutuhkan, (iv) faktor atraksi wisata yang terdiri dari kemampuan daya tarik wisata, jenis daya tarik wisata yang diminati 
oleh wisatawan, dam aktivitas wisata yang dilakukan wisatawan di destinasi pariwisata pantai.

Berdasarkan keempat faktor yang mempengaruhi preferensi dan rute diperoleh faktor yang paling mempengaruhi yaitu faktor sosio-demografis wisatawan. Daerah asal dan sumber informasi wisatawan sangat mempengaruhi preferensi dan rute dimana wisatawan akan memilih destinasi pariwisata pantai yang searah dengan arah perjalanan mereka dari dan menuju ke daerah asal. Selain itu, sumber informasi juga sangat mempengaruhi preferensi dan rute wisatawan dimana wisatawan berdasarkan sumber informasi yang diperoleh terkait destinasi pariwisata pantai akan tertarik untuk berkunjung ke destinasi pariwisata pantai tersebut.

Rekomendasi yang dapat diberikan dari hasil penelitian ini yaitu diperlukan adanya penyediaan akses jaringan jalan dengan kondisi yang baik sehingga dapat menambah daya tarik serta memudahkan wisatawan untuk mencapai destinasi pariwisata pantai yang dituju, diperlukan adanya penambahan informasi pariwisata baik berupa iklan, media sosial, media massa, atau melalui website resmi sehingga wisatawan dapat lebih mudah mengetahui informasi terkait destinasi pariwisata pantai.

Penelitian mengenai preferensi dan rute destinasi pariwisata sudah banyak dilakukan dengan temuan faktor-faktor yang sangat beragam. Selain itu, dari penelitian ini diperoleh hasil bahwa terdapat destinasi pariwisata pantai yang jarang dilewati oleh wisatawan. Untuk itu pada penelitian selanjutnya dapat meneliti lebih jauh mengenai potensi dan masalah yang terdapat di destinasi pariwisata pantai tersebut sehingga diharapkan dapat meningkatkan daya saing pariwisata.

\section{DAFTAR PUSTAKA}

Arikunto, Suharsimi. 2010. Prosedur Penelitian : Suatu Pendekatan Praktek. Jakarta : Rineka Cipta.

Badan Pusat Statistik (BPS) DIY. 2011-2017. Daerah Istimewa Yogyakarta Dalam Angka 2011-2017. Daerah Istimewa Yogyakarta : Badan Pusat Statistik Daerah Istimewa Yogyakarta.

Burhan, B. 2005. Metodologi Penelitian Kuantitatif. Jakarta : Kencana Prenada Media Group.
Dinas Pariwisata DIY. 2010-2017. Buku Statistik Kepariwisataan Daerah Istimewa Yogyakarta Tahun 2010-2017. Daerah Istimewa Yogyakarta : Dinas Pariwisata DIY.

Kementerian Hukum dan Hak Asasi Manusia RI. 2011. Peraturan Pemerintah Nomor 50 Tahun 2011 Tentang Rencana Induk Pembangunan Kepariwisataan Nasional Tahun 2010-2025, Jakarta : Kementerian Hukum dan Hak Asasi Manusia Republik Indonesia.

Kementerian Pekerjaan Umum Republik Indonesia. 2010. Peraturan Menteri Pekerjaan Umum Nomor 09 Tahun 2010 Tentang Pedoman Pengamanan Pantai. Jakarta : Kementerian Pekerjaan Umum Republik Indonesia.

Kerlinger, F.N., 1973. Founding of Behavior Research. New York : Rinchart and Winston Inc.

Pemerintah RI. 2009. Undang-Undang RI Nomor 10 Tahun 2009 Tentang Kepariwisataan. Jakarta : Kementerian Hukum dan Hak Asasi Manusia Republik Indonesia.

Sugiyono. 2009. Metodologi Penelitian Pendidikan, Pendekatan Kuantitatif, Kualitatif, dan R\&D. Bandung: Alfabeta. 


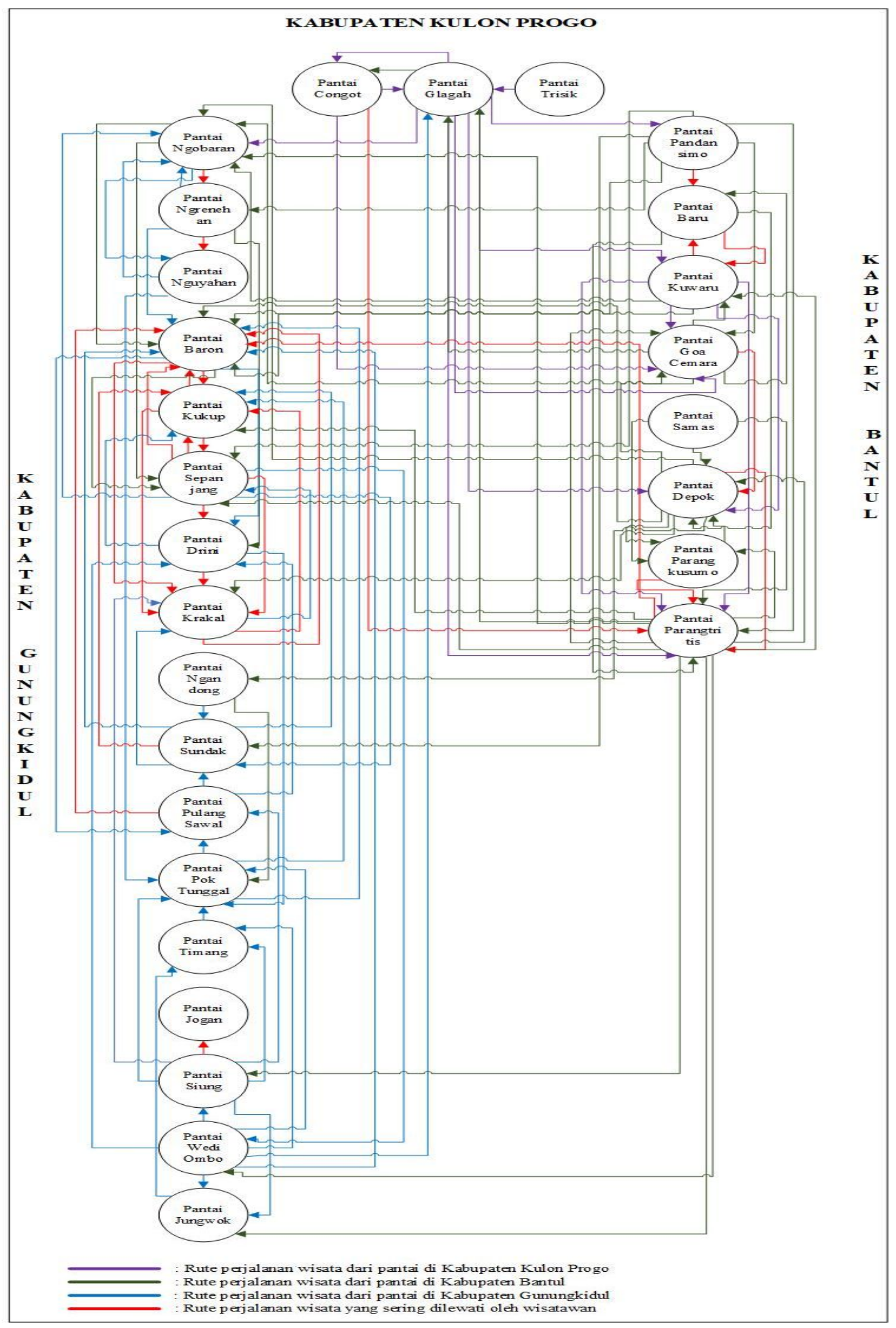

Gambar 14 Skema Rute Destinasi Pariwisata Pantai 
